Mr Darko Vasiljevic, dipl. inž.,

Ur Dragoljub Ridołić, kapetan I klase, dipl. inž.

\section{Automatizacija procesa projektovanja optičkih sistema pomoću računara}

\section{Uvod}

Razvoj modernih optičkih i optoelektronskih sistema zahteva mikrooptičke elemente, optičke modulatore povećane preciznosti, ogledala specijalnih zahteva, optičke poligone za skanirajuće sisteme, retroreflektore, delitelje svetla, fiber optičke komponente, fotoprijemnike razlicitih izvedbi i namena, komponente integralne optike, laserske komponente, opticke komponente IC tehnike, i sl. Ovakvim razvojem nametnuti su stroži zahtevi za optičke elemente i sisteme, što iziskuje razvoj optičkih komponenti specijalnog oblika i namene, kao što su asferici, prozori i objektivi velikih dimenzija, ogledala na bazi metala, te razni elementi sa urezanim žlebovima i rupama. Dobiti odgovarajući kvalitetan optički sistem uslovijeno je nizom uzajamno povezanih, a često i kontradiktornih faktora. Pred projektanta se, dakle, nameću ti složeni zahtevi. Tri su osnovna zadatka koja se nameću za rešavanje, a to su:

- izbor pogodnih elemenata i njihovih gabarita, čime treba da se zadovolje postavljeni tehnički uslovi (optičke karakteristike, geometrijski parametri);

- kroz aberacioni proračun neophodno je obezbediti određeni kvalitet slike, vodeći računa o tolerancijama izrade optičkih elemenata. Pri tome tole- rancije treba da budu tako definisane da se ne ide u njihove uske granice, ako se ne želi bitno izgubiti u kvalitetu slike;

- tehnološka realizacija optičkog sistema i njegova cena.

$\mathrm{U}$ ovam radu daje se kraći osvrt na puteve koji su od vitalnog značaja za svaki projekat optickog sistema uz ukazivanje na dalje perspektive i moguće pravce razvoja i usavršavanja prezentiranih varijanti.

\section{Hronologija razvoja projektovanja optičkih sistema}

Teorija optičkih sistema (optical design) jedna je od najstarijih grupa fizike sa istorijom dugom preko tri stotine godina. Da bi se mogao projektovati optički sistem, potrebno je definisati mogućnost proračuna prostiranja zraka knoz optički sistem, što zahteva poznavanje zakona prelamanja svetlosti $\mathrm{i}$ trigonometrije.

William Gascoigne je prvi proračunao prostiranje zraka kroz optički sistem koje se od tada naziva proračun hoda zraka kroz optički sistem. Gascoigne nije sam objavio svoju metodu, jer je poginuo 1641. kada je imao samo 24 godine, ali je sa njom upoznao Flamsteeda, prvog engleskog kraljevskog astronoma (Astronomer Royal). 
Sve do XIX veka, zbog velikog broja funkcionalnih zahteva u proračunu, kao i relativno netačnih ulaznih podataka, nije se koristio egzaktan proračun hoda zraka. Umesto toga, vršeno je eksperimentisanje sa ulaznim parametrima služeći se ličnim iskustvima.

Situacija u projektovanju optičkih sistema bitno se menja sa uvođenjem teorije primarnih aberacija koja je nastala na osnovu Seidelovih radova. Rani oblici te teorije bili su prilično glomazni, i nisu bili od velike koristi projektantima optičkih sistema, ali teorija, koju su koristili mnogi projektanti, postepeno se usavršavala sve dok, pri kraju devetnaestog veka, nije postala primenljiva. Jedan od njih je $H$. D. Taylor, koji je, koristeći Seidelovu teoriju primarnih aberacija, projektovao Cookov triplet 1893.

Sa prvim godinama dvadesetog veka proracun hoda zraka kroz optički sistem postepeno postaje lakši kako se pojavljuju mehaničke mašine za računanje. Paralelno sa tim raste i značaj proračuna hoda zraka kroz optički sistem. Za vreme drugog svetskog rata vecina optičkih proizvođača zapošljavala je veliki broj službenika, obično devojaka, da vrše proračun hoda zraka kroz optički sistem. Proračun je tekao prilično sporo, a postojao je i veliki rizik od grešaka.

Pojava EINAC računara 1946. je na spektakularan način označila ulazak računara u naučne proračune. Jedna od prvih upotreba račnara bila je njihovo testiranje pomoću optickih proracuna, jer su ih jedino optičari poznavali do detalja, pa se mogla proveravati tačnost računara.

Programi za projektovanje optičkih sistema pravljeni su skoro za svaki računar koji se pojavio. Računar IBM 650 bio je prvi pouzdan računar i on je promenio način rada programera, jer oni više nisu tražili hadversku već samo softversku gresku. $\mathrm{Na}$ svakom nivou razvoja računara projektantima optičkih sistema bila je potrebna sve veća brzina više memorije i niža cena proračuna. Kako se povećavala brzina rada računara, tako su se pojavljivale nove oblasti za projektovanje optickih sistema.

Kompjuterska revolucija dovela je do povećanja u brzini proračuna hoda zraka kroz optički sistem sa jedne zrak-površine na minut na nekoliko hiljada zrak-površina na sekund. Možda je najznačajniji doprinos kompjuterske revolucije bio uklanjanje mukotrpnog ručnog proračuna i rizika greške u starim metodama proračuna optičkih sistema.

$\mathrm{U}$ jednom od ranih radova Feder [1] je opisao jednačine za proračun hoda zraka koje su koristile samo 4 osnovne računske radnje i korenovanje za razliku od klasične metode koja je koristila trigonometrijske formule. U takvom obliku one su bile veoma pogođne za upotrebu na velikim računarima. Danas najveći broj komercijalnih programa koristi neki oblik metode prigusenih najmanjih kvadrata. Metoda najmanjih kvadrata poznata je još iz XIX veka, ali se ona u praksi mogla primeniti tek sa pojavom računara. U optici ju je prvi primenio Wynne [2]. Današnji optički i optoelektronski sistemi ispunjavaju vrlo složene funkcionalne zahteve, zahvaljujući prvenstveno dobrim mogućnostima automatskog projektovanja njihovih komponenti i sistema u celini. U našoj zemlji u razvoj $i$ istraživanja $u$ proračun $i$ projektovanje takvih sistema uložena su određena sredstva u kadrove, tehnologiju i opremu, sto je rezultiralo značajnim napretkom ove oblasti. Međutim, potrebno je naglasiti da se kod nas jos uvek neki problemi optičkih konstrukcija mogu samo teorijski rešavati (asferične površine), a praktično traže slična rešenja koja bi, eventualno, nadomestila takve mogućnosti.

$\mathrm{Na}$ svetskom nivou ulaganja su znatno veća, gde prednjače Japanci, Nemci, Englezi, Francuzi i SAD, pa je i automatsko projektovanje optičkih sistema daleko ispred naših mogućnosti. 
Za procenu kvaliteta optičkih sistema danas se, uglavnom, koristi metoda optičke prenosne funkcije (Optical Transfer Function - OTF). Primena ove metode počela je pre nekoliko decenija, a njene teorijske osnove i eksperimentalno istraživanje se usavršavaju i danas.

\section{Delinicija automatizacije procesa projektovanja optičkih sistema}

Danas se često piše o automatizaciji jrocesa projektovanja optičkih sistema pomoću računara. Pojedini autori idu toliko daleko da najavljuju u doglednoj budućnosti potpunu automatizaciju procesa projektovanja optičkih sistema i potpuno izbacivanje projektanta iz tog procesa [3]. Projektant bi zadavao opšte početne uslove, a program bi sam pronalazio najbolji mogući optički sistem. Najveći broj komercijalnih programa za projektovanje optickih sistema ima prethodno definisane funkcije za ocenu koje su veoma efikasne $u$ pronalaženju novih tipova optičkih sistema. Ipak, ako se koristi prethodno definisana funkcija za ocenu bez ikakvih izmena, tada projektant optičkih sistema nije projektant, jer proces projektovanja uključuje i proces promene svih početnih veličina i njihovih težinskih faktora. Takođe je neophodno da se postavi pitanje neophodnosti svakog optičkog elementa, korišćenog materijala, načina izrade, testiranja, montiranja, cene, i dr. Bilo bi loše kada bi projektant prihvatio prethodno definisane vrednosti funkcije za ocenu bez ikakvih izmena. One su dobre samo kao polazne osnove koje on mora da sagleda sa svih strana. Zato, sve dok projektanti donose ključne odluke o optičkom sistemu, moguće je govoriti samo o automatizaciji procesa projektovanja optickih sistema u smislu automatskog proračuna kvaliteta optičkog sistema, a nikako o potpunoj automatizaciji procesa projektovanja optičkog sistema.
Pod automatizacijom procesa projektovanja optičkih sistema može se podrazumevati uvođenje programskih paketa koji na principima skaniranja određuju prolazak svetlosnih snopova koji upadaju pod različitim uglovima na optički sistem, pri čemu se omogućuje proračun hoda zraka kroz optičkil sistem i aberacija pomoću refleksije ili refrakcije zraka na proizvoljnoj optičkoj površini, bilo da je ona ravna, sferna ili asferična, centrirana ili decentrirana.

Zahtevi koji se nameću za rešavanje u tim programskim paketima određeni su namenom, funkcijom i uslovima eksploatacije željenog optičkog sistema. U skladu sa tim, projektant daje idejnu zamisao kod koje se očekuje da će biti ispunjeni takvi zahtevi, definišu se početri ulazni podaci (konstrukcioni parametri - geometrijski i optički). $\mathrm{Na}$ slici 1 dat je pojednostavljeni dijagram toka projektovanja optičkih sistema, odakle se jasno vidi redosled radnji i aktivnosti koje treba da sledi programski paket.

Unošenje konstrukcionih podataka podrazumeva parametre, kao sto su: radijusi krivina prelomnih površina, njihova međusobna rastojanja, svetlosni i mehanički otvor optičkih komponenti, indeksi prelamanja optičkih sredina, uvećanje, numerička apertura i položaj aperturne dijafragme, ugao vidnog polja i vrednosti talasnih dužina na kojima radi optički sistem.

Pomoću težinskih faktora reguliše se proces optimizacije optičkih sistema. Za njihovu optimizaciju najčešce se koristi metoda prigušenih najmanjih kvadrata u kojoj se funkcija za ocenu koja se minimizira sastoji od zbira kvadrata pojedinih aberacija koje se usklađuju pomoću težinskih faktora. Postavljanje graničnih uslova omogućava programu realizaciju optičkog sistema koji se može fízički napraviti i koji zadovoljava sve projektantove zahteve u pogledu ciljnih parametara optickkog sistema. 
Definisanje ulaznih podataka

-Konstrukcioni parametri ( geometrijski i opticki)

-Tezinski faktori aberacija, granicni uslovi na diopterskim porrsinama i ciljni parametri optickog sistema

-Koordinate ulaznog zraka

Variranje dozpoljenilh konstruketonih parametara optickog sistema

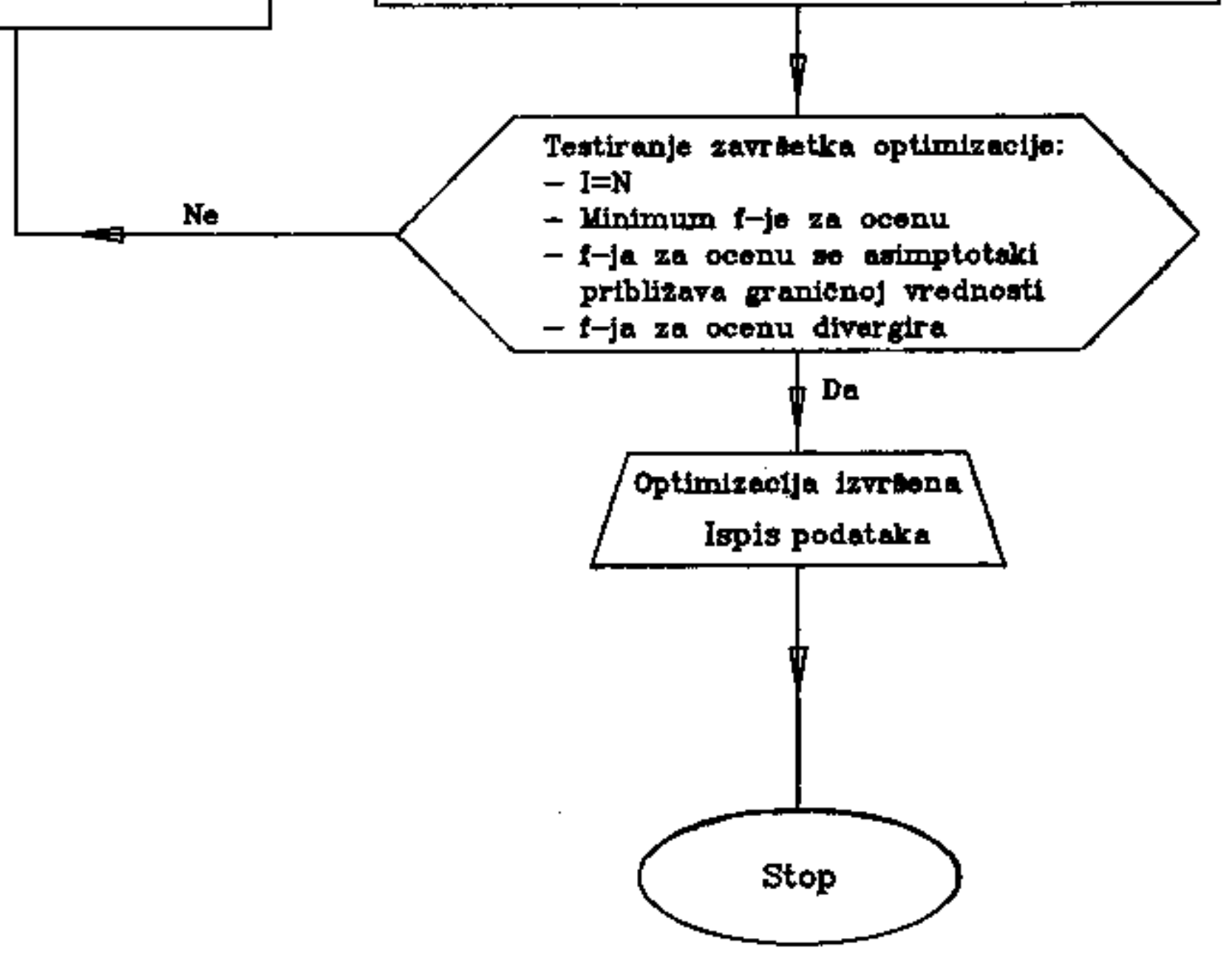

Proracun kraliteta lika optickog sistema ( aberacije, MTF-geometrijski i difrakcioni spot djagram)

Sl. 1 Dijagram toka projektovanja optičkog sistema 
Kordinate ulaznih zraka definišu položaj upada snopa svetlosnih zraka na prvu prelomnu površinu optickog sistema pomoću kojih se ulazi u proračun kvaliteta lika optickog sistema.

Proces optimizacije vrši se u odredenom broju iteracija, pri čemu se ide prvo u proračun kvaliteta lika optick kog sistema. Proracun obuhvata podužne i poprečne aberacije, geometrijsku aproksimaciju MTF (MTF - Modular Transfer Function - modularna prenosna funkcija), difrakcioni MTF i spot-dijagram. Nakon proračuna na ekranu i štampaču moguće je dobiti rezultate proračuna tabelarno i/ili grafički.

Izlazak iz procesa optimizacije vrši se kada su ispunjeni sledeći uslovi:

nimum,

- funkcija za ocenu asimptotski se približava određenoj vrednosti,
- funkcija za ocenu divergira, iteracija.

- izvršen unapred određen broj

U slučaju kada nisu ispunjeni navedeni uslovi, vrši se variranje konstrukeionih parametara dok se ne ispune ti uslovi, tj. dok optički sistem ne dobije optimalni kvalitet lika [4].

\section{Korelacija između MTF i realnih optičkih sistema}

OTF predstavlja funkciju koja opisuje sposobnost optičkog sistema da preslika raspodelu svetlosnog intenziteta iz ravni predmeta na ravan slike. $\mathrm{Na}$ osnovu same definicije OTF proizilazi i njen znacaj, a to je davanje mogućnosti rekonstrukcije lika optičkog sistema, ako je poznata raspodela svetla u ravni predmeta.

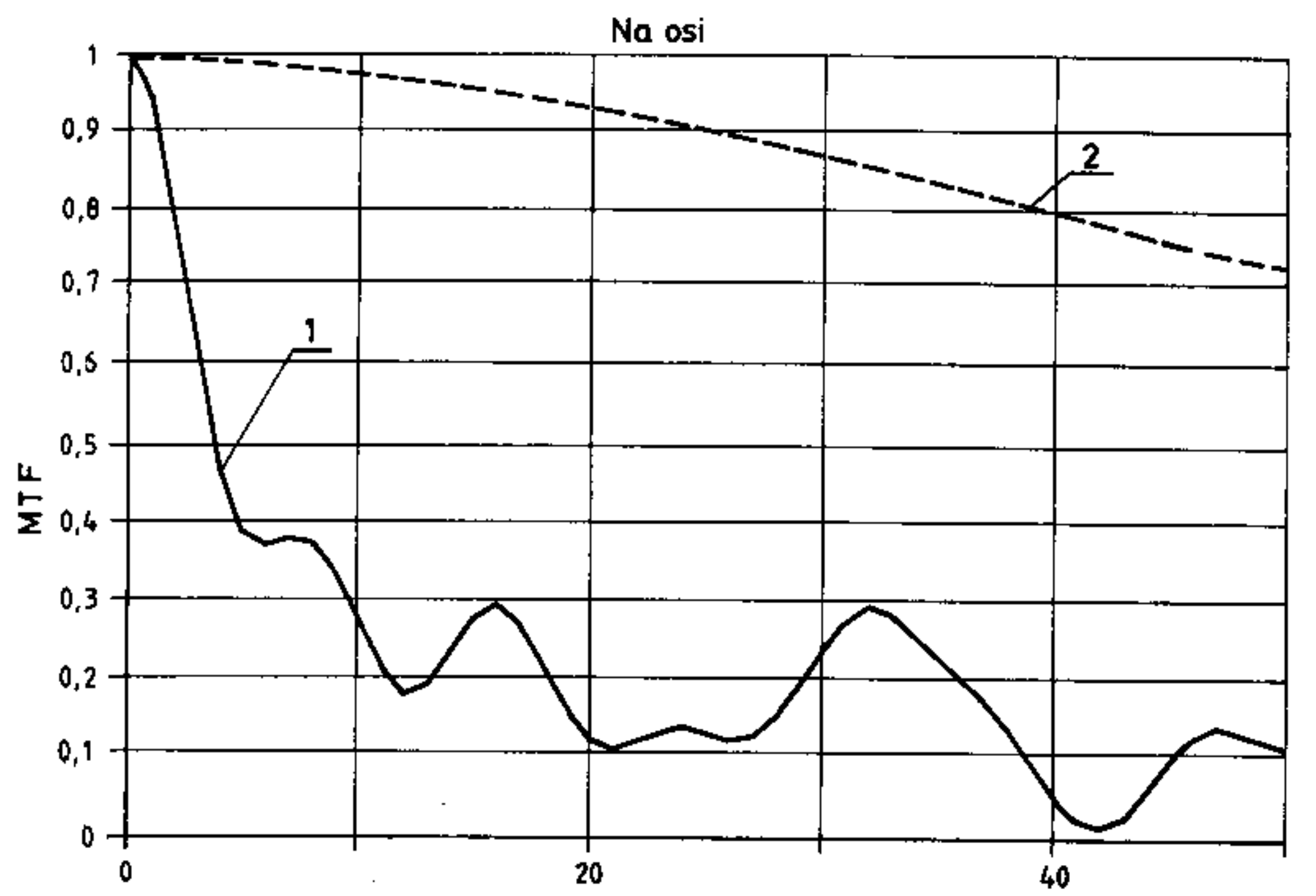

Prostorna frekfencija [linijskih parova/mm ]:

1-osnovna varijanta; 2-optimizirana varijanto

S1. 2a - Uporedni prikaz MTF-a (sagitalna - SAG i tangencijalna - TAN) za polazni i optimizirani opticki sistem (na osi optickog sistema) 
Pri analizi optičkih sistema pomocu OTF, koristeći se Fourierovim transformacijama, dobija se funkcija koja govori o sposobnosti sistema da preslika periodičnu raspodelu svetla iz ravni predmeta u ravan lika. Prisustvo abe-
MTF pokazuje kolika je relativna kontrasna osetljivost optickog sistema, a PTF određuje pomak slike u odnosu na opticku osu za vanosne svetlosne snopove. Sa fizikalnog stanovišta veći značaj ima MTF u odnosu na PTF, jer

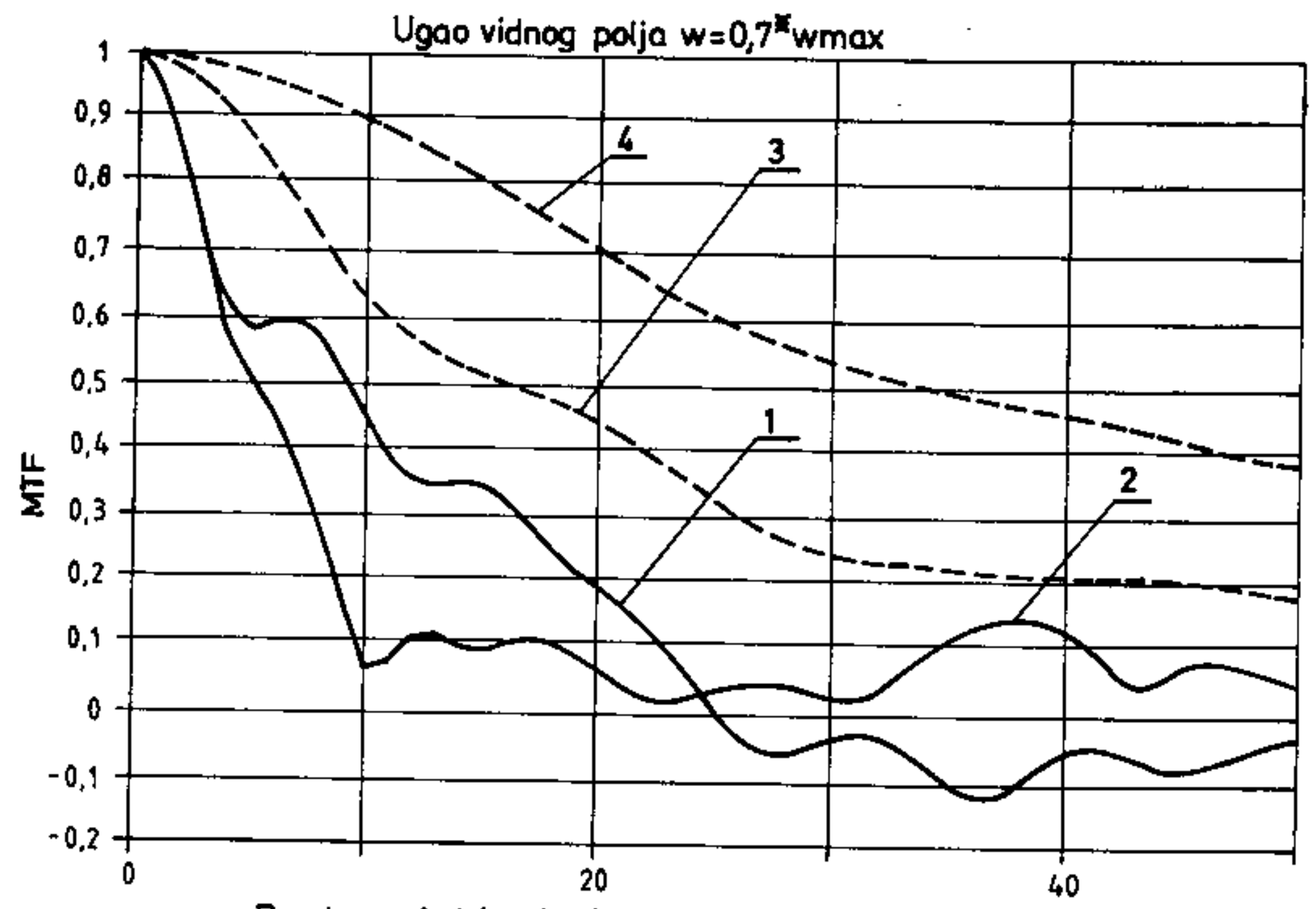

Prostorna frekfencija [linijskih parova/mm ]:

1-MTF-SAG osnovni; 2-MTF-TAN osnovni; 3-MTF-SAG optimiziran; 4-MTF-TAN optimiziran.

Sl. $2 b$ Uporedni prikaz MTF-a za polazni i optimizirani optički sistem (za 0,7 od ugla vidnog polja)

racija i difrakcije svetlosti u optičkom sistemu onemogućava razlikovanje kontrasta svetlih i tamnih polja ukoliko prostorna frekvencija bude ispred neke granične vrednosti koja je uslovljena karakteristikama optickog sistema.

U opštem sIučaju OTF predstavlja kompleksan izraz koji se može prikazati u Eulerovoj formi:

$$
\mathrm{OTF}=\mathrm{MTF} \cdot \mathrm{e}^{\mathrm{t} \cdot \pi \cdot \mathrm{PTF}}
$$

gde je:

PTF - fazna prenosna funkcija (Phase Transfer Function). on opisuje raspodelu svetla u periodičnom testu. Zato je najprikladnije da bude neka harmonijska funkcija (sinusna funkcija), jer je Fourierova transformacija takve funkcije opet harmonijska funkcija. Za sinusni test MTF predstavlja odnos između relativnih kontrasta svetla $u$ ravni lika $\left(\mathrm{K}_{t}\right)$ i ravni predmeta $\left(K_{n}\right)$.

$$
\mathrm{MTF}=\frac{\mathrm{K}_{\mathrm{t}}}{\mathrm{K}_{\mathrm{o}}}
$$

MTF je funkcionalno zavisan od prostorne frekvencije upotrebljenog pem 
riodičnog testa $\mathrm{i}$ od azimutnog ugla (ugao između testa i meridionalne ravni). Ukoliko je izražen porast prostorne frekvencije, onda MTF opada utoliko brže što je uticaj aberacija i difrakcije u sistemu veći. Obično se računa MTF i meri za azimutni ugao od $90^{\circ}$ (tangencijalni MTF) i za $0^{\circ}$ (sagitalni MTF). Razlika između sagitalne i tangencialne komponente MTF prisutna je samo u slučaju kada se periodični test nalazi izvan ose optičkog sistema. Na slici 2a, b i c dat je prikaz MTF za osnovni i optimizirani opticki sistem pomoću programa APOS. Granicu razlaganja nekog optičkog sistema definise iznos modulacije koju sistem može detektovati, pri cemu treba imati na umu da ona ne od. ređuje u potpunosti osobine sistema. Ukoliko bi imali dva optička sistema sa istim graničnim iznosom razlaganja, onda bi odabrali onaj koji ima bolji kontrast za linijski par po milimetru (Lp) $/ \mathrm{mm}$ ). Nešto složenija varijanta izbora bila bi za optičke sisteme od kojih jedni imaju visoku granicu razlaganja i lošiji kontrast, a drugi nižu granicu razlaganja i bolji kontrast. Za takve slučajeve treba se odlučiti za ono rešenje koje trenutno predstavlja veću važnost, a to je pitanje kontrasta ili razlaganja, što će, svakako, uticati na namenu samog sistema [5].

\section{Opis programa APOS}

Program APOS (Automatsko Projektovanje Optickih Sistema) namenjen je onima koji se bave projektovanjem optičkih sistema. Zamišljen je kao integrisana programska celina. To znači

Ugao vidnog poljo $w=$ wmax

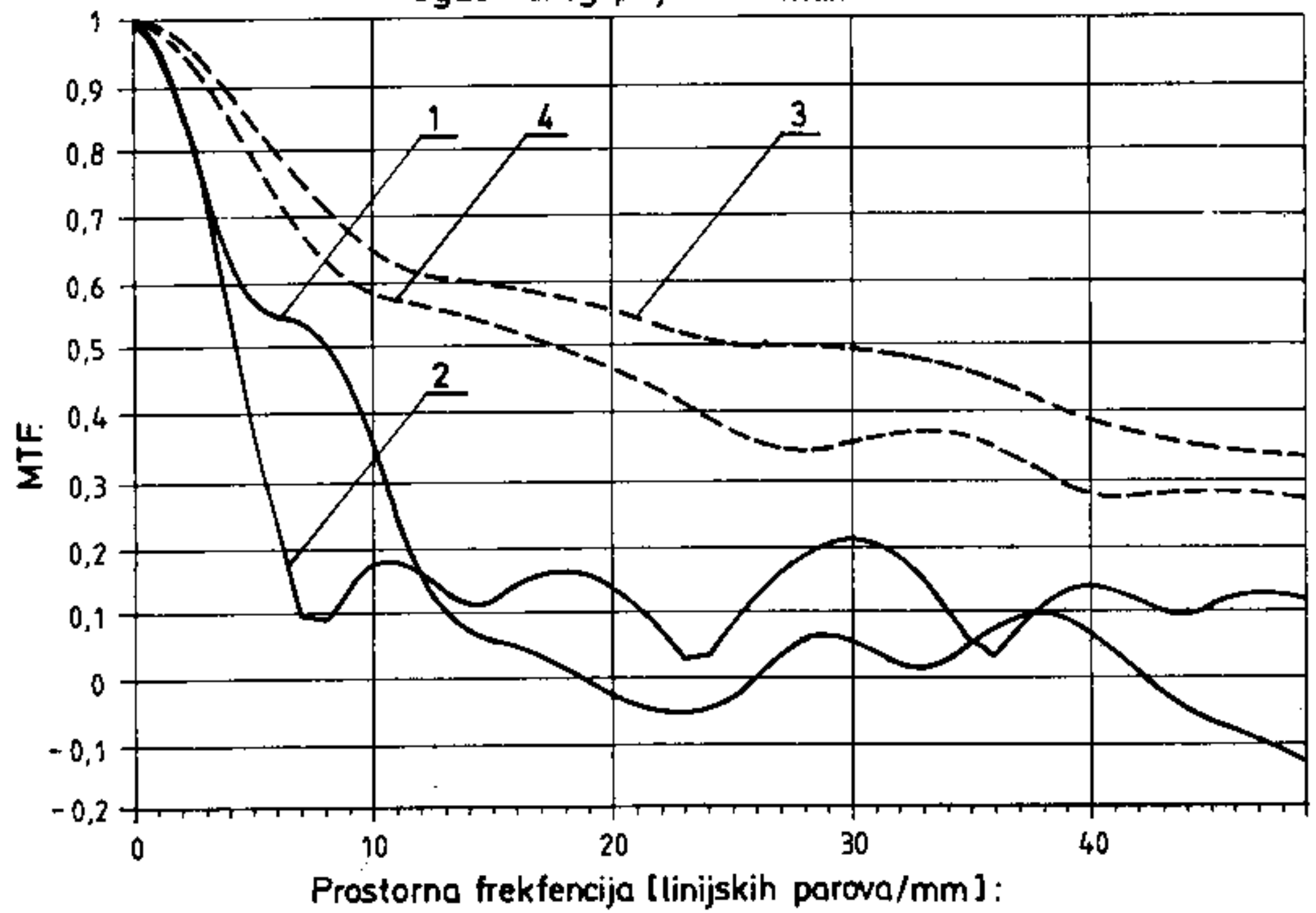

1-MTF-SAG osnovnI; 2-MTF-TAN osnovni; 3-MTF-SAG optimiziran; 4-MTF-TAN optimiziran

Sl. 2c Uporedni prikaz MTF-a za polazni i optimizirani opticki sistem (za puni ugao vidnog polja) 
da bi projektant optičkih sistema mogao da obavi sve potrebne faze projektovanja optičkog sistema u okviru programa, ne izlazeći nikad na nivo operativnog sistema. Kada jednom startuje program projektant može da:

I definiše polazne podatke za novi sistem koji obuhvataju:

a) opšte optičke parametre:

- izbor talasnih dužina za proračun optičkog sistema;

- određivanje broja prelomnih površina optickog sistema; lju;

- definisanje broja pozicija u po-

- određivanje položaja aperturne đijafragme i numeričke aperture;

- izbor uvećanja optičkog sistema;

b) konstrukcione parametre:

- labela optiðke površine koja pokazuje na tip opticke površine (sferična ili asferična) i koji se od konstrukcionih parametara (radiusi, rastojanja ili staklo) mogu menjati prilikom optimizacije, vršine,

- radijus ili krivina prelomne po-

- rastojanje izmedu prelomnih površina,

- naziv stakla po Schottovom katalogu (indeksi prelamanja i disperzija se dobijajı iz odgovarajuće baze podataka),

- maksimalna visina, odnosno polovina slobodnog svetlosnog otvora;

c) kordinate ulaznih zraka (šeme zraka) koje mogu biti:

- kreirane, kod kojih se unose samo uglovi vidnog polja, a sam program na unapred utvrđen način formira mrežu ulaznih zraka relativno u odnosu na glavni zrak,

- relativne, kod kojih se ručno unose kordinate ulaznih zraka relativno u odnosu na glavni zrak,
- normalne, kod kojih se ručno unose apsolutne kordinate ulaznih zraka na prvoj prelomnoj površini;

d) težinski faktori aberacija, granični uslovi na diopterskim površinama i ciljni parametri optičkog sistema se ne unose prilikom definicije novog optičkog sistema. Tada im se dodeljuju podrazumevane (default) vrednosti koje se prilikom optimizacije mogu i treba da promene;

II prikaže podatke i rezultate proračuna hoda zraka kroz optički sistem, bilo u numeričkom ili grafičkom obliku, kako na ekranu, tako i na štampaču;

III ispiše podatke na datoteku u formatu pogodnom za učitavanje u AutoCad koji čine osnovu za kompletno projektovanje sistema i izradu cele konstrukcione doktumentacije.

IV izvrši potpunu analizu, kako aberacionu, tako i energetsku optičkih sistema.

1. - Aberaciona analiza sadrži prikaz sleđećih aberacija:

a) aberacije osnih zraka:

- sferna ili sferohromatska podužna aberacija,

- sferna ili sferohromatska poprečna aberacija,

- odstupanje od sinusnog uslova,

— izoplanetizam,

b) aberacije glavnog zraka za fokalne i afokalne sisteme:

- astigmatizam,

- krivina polja,

- distorzija,

- hromatizam povećanja;

$\mathrm{Za}$ afokaIne sisteme još se računaju i sledeće aberacije:

- sferna i sferohromatska aberacija glavnog zraka,

- hromatizam glavnog zraka, 
- sferna i sferohromatska aberacija izlazne pupile,

- hromatizam izlazne pupile,

c) aberacije kosih zraka:

- odstupanje kosih zraka (gornjeg i donjeg) u odnosu na glavni zrak,

- koma,

2. - Energetska analiza u sebi sadrži sledeće:

- proračun spot-dijagrama za različite talasne dužine,

- pronalaženje ravni najboljeg lika pomoéu spot-dijagrama,

- uporedni proračun spot-dijjagrama i MTF,

- proraéun MTF za različlte tam lasne dužine,

- pronalaženje ravni najboljeg lika pomocu MTF,

V izvrši optimizaciju optičkih sistema (pomocu metode prigušenih najmanjih kvadrata),

VI rad sa bazama stakala različitih optičkih proizvođača. Trenutno se radi samo sa bazom Schottovih stakala, a planira se formiranje i sledećih baza stakala: Corning France i Chance-Pilkington.

VII mogućnost izmene (editovanja) bilo kojeg potrebnog podatka,

VIII mogućnost skaliranja optičkih sistema za zadati faktor ili na zadatu žižnu dužinu.

Slično mnogim komercijalnim programima i program APOS je korisnicki orijentisan (user friendly). To znači:

- da se sve mogućnosti programa mogu dobiti iz raznih menija,

- da greška u unosu podataka ne izaziva prekid rada programa već samo poruku o grešci i omogućava ponovni unos pođataka,

- da se iz svakog menija može izaći sa pritiskom na Esc ,
- da je ekran podeljen na nekoliko preklapajucih prozora u kojima su prikazani odgovarajući podaci koji se ne mogu međusobno mešati,

- da je pomoć (help) uvek dostupna korisniku.

Ove osobine programa APOS su veoma bitne i njima je pri programiranju bila posvećena velika pažnja, jer prosečni korisnik programa, projektant optičkih sistema, najviše vremena provodi baš u unošenju i uređivanju (editovanju) unetih podataka.

\section{Neka poređenja programa APOS sa drugim programima: SIGMA PC i SOLORD}

Program APOS, pisan na Turbo, Pascalu, nastao je kao rezultat višegodišnjeg istraživanja kod nas. Njegov razvoj počeo je 1988, a njegovo usavršavanje jos uvek traje.

Program SIGMA PC verzija 1.5 od jula 1987, firme Kidger Optics, pisan je na Quick BASIC-u. Program vodi poreklo sa grupe za optical design sa Imperial Coledgea koja je počela sa istraživanjem 1959. Program SIGMA radi na više računara (Hewlwtt Packard Series 200 - SIGMA200, Hewlwtt Packard Series 300 - SIGMA300, IBM PC od 1983. godine i Apple Macintosh - MacSIGMA).

Program SOLORD, verzija $2.02 \mathrm{iz}$ 1989. (demo verzija), firme Lord Ingenierie pisan je na Turbo C-u. Firma Lord osnovana je 1985. i od tada se, između ostalog, bavi i razvojem optičkih programa.

Osnovni razlog zašto se krenulo $u$ razvoj sopstvenog programskog rešenja za automatsko projektovanje optičkih sistema je mogućnost da se programska rešenja neprekidno prilagođavaju cestim nestandardnim zahtevima projektanata složenih optickkih i optoelektronskih sistema. 
U deset godina kako se razvijaju programi za IBM PC računare iskristalisao se jedan način razvijanja programa koji su potpuno korisnički orijentisani. Programi APOS i SOLORD potpuno zadovoljavaju te kriterijume, jer gu nastali na IBM PC računarima, a za razvoj su korišćeni najmoćniji dostupmi programski jezici. Program SIGMA PC samo delimično zadovoljava te kriterijume (ima pođršku funkcijskih tastera, ali zato nema pođršku menija, preklapajucíh prozora i uvek prisutne podrške korisniku) zato što je izabran BASIC programski jezik da bi se obezbedila laka prenosivost sa jednog računarskog sistema na drugi.

Sva tri programa koriste slicne veličine kao ulazne podatke i zapisuju ih $\mathrm{u}$ tekstualnu datoteku za kasnije korišcenje. $\mathrm{Na}$ osnovu te sličnosti bilo je moguće razviti proceduru koja vrši konverziju iz ulaznih podataka za APOS u ulazne podatke za SIGMA PC, i obrnuto.

Program SIGMA PC je najmoćniji od tri poređena optička programa, jer omogućava neke stvari koje ne nude druga dva programa, kao što su difrak'cioni MTF, veliki izbor optičkih povrsina, projektovanje i optimizaciju zoom-sistema.

Tri stvari posebno izdvajaju program APOS u odnosu na ostale programe, a to su:

- direktna veza sa AutoCAD-om. Program APOS formira script-datoteku (datoteka posebnog formata koja sadrži naredbe samog AutoCAD-a) koja služi kao polazna osnova za kompletno projektovanje optickih i optoelektronskih uređaja na Auto-Cad-u i kasniju izradu celokupne tehničke dokumentacije;

- kompletan sistem za rad sa bazama podataka o staklima koji je zasnovan na modifikovanom algoritmu binarnog stabla (btree+);

- veoma detaljan aberacioni proračun optickih sistema.

\section{Perspektive razvoja projektuvanja optičkih sistema}

Danas u svetu postoji nekoliko odličnih komercijalnih programa za projektovanje svih vrsta optičkih sistema koji su potrebni. Budući korisnici ovih programa treba da shvate da ce projektovanje optičkih sistema pomoću ovih programa samo prvi korak u pravljenju optičkih sistema koji su deo nekog uređaja ili instrumenta. Cena projektovanja optičkog sistema je mali deo cene ukupnog razvoja instrumenta, ali on bi bio beskoristan ako optički sistem ne bi imao predviđene karakteristike. Sagledavajući sve ove potrebe, moguce je predvideti pravce daljeg razvoja programa za projektovanje optičkih sistema:

\section{- Korišćenje postojeće optike}

Novi optimizirani optički sistemi nisu potrebni u svim prilikama. Ako postojeći optički sistem zadovoljava postavljene zahteve, on se može kupiti i na taj način skratiti vreme razvoja optickog sistema i cenu njegovog koštanja, jer se preskače faza prototipa. Danas postoje efikasne metode za proveru kvaliteta lika optickog sistema, kako numerickim putem, tako i eksperimentalno. Da bi se ova mogućnost mogla iskoristiti, potrebno je napraviti bazu podataka o svim komercijalno dostupnim optičkim sistemima koja bi se stalno ažurirala.

\section{- Mehaničko projektovanje optičkih sistema}

Programi za optičko projektovanje treba da se povežu sa sadašnjim i budućim CAD programima (CAD Computer Aided Design - Projektovanje pomoću računara). Mehaničko projektovanje optizkih sistema je zajednički zadatak projektanta optickih sistema i mašinskih inženjera. U procesu projektovanja mora se obezbediti stalna komunikacija između projektanta optickih sistema i mašinskih inženjera i povratna veza između programa za pro- 
jektovanje optičkih sistema i CAD programa.

\section{- Testiranje u toku proizvodnje}

$\mathrm{Da}$ bi se napravili komplikovani optički sistemi, potrebno je da se testiraju i mere mnogi koraci koji se preduzimaju za vreme sklapanja optičkih sistema. Moderni računari kontrolisani laserski interferometri su neophodni za proveru individualnih prelomnih površina. Svaki optički element treba detaljno testirati pre nego što se ugradi $\mathrm{u}$ optički sistem. Ovakav postupak je dugotrajniji i skuplji, ali se brzo isplati, jer ako se ugradi neki defektni deo, može potpuno da onesposobi opticki sistem, a zadatak da se on pronađe još je dugotrajniji i skuplji.

\section{Zaključak}

Proces automatizacije projektovanja optickih sistema nezamisliv je bez kompjuterske tehnike. Razvoj hardve-

\section{Literatura:}

[1] Feder D. P.: DOptical calculations with automatic computing machinery*, JOSA vol. 41 no. 9, 1951.

[2] Wynne C. G.: sLens deglgning by electronic digital computers, Proceedings of Physics soclety vol. 73 no. 5, 1959 .

[3] Feder D. P.: \Automatic optlcal deaignc, Applied optics vol. 2 no. $12,1963$. ra omogućio je i softversku podršku koja, uz odgovarajući algoritam, dosta uspešno rešava probleme dizajna optičkih konstrukeija. Na taj način se dosta brzo i vrlo precizno određuju odgovarajući konstrukcioni parametri koji omogućavaju optimalni kvalitet slike. Specifikacija, testiranje optičkih sistema uz kompleksne informacije o uticaju aberacija, difrakcije na proces preslikavanja znatno je poboljšano korišćenjem odgovarajućih programskih paketa. Program APOS, koji je razvijen kod nas, omogućava:

- projektovanje optickih sistema uz optimizaciju kvaliteta lika;

- uticaj projektanta preko težinskih faktora aberacija i drugih parametara koji se definišu preko ulaznih podataka, na dalji tok procesa optimizacije.

Radi poboljšanja prezentiranog modela neophodna su dalja proširenja koja bi obuhvatala probleme dizajna tankoslojne strukture.

[4] Vasiljevic D. M. \$Prilog optimizacfjl projektovanja optickih sistema pomoć mikroraćunaraa, Magistaraka teza, Maß̌insk1 fakultet, 1991.

[5] J. Mecdonald: $>$ The calculation of the optical transfer functiona, Optica Acta no. 18, 1971. 